\title{
Pengembangan Perangkat Pembelajaran Kooperatif dengan Pendekatan Struktural Numbered Heads Together (NHT) Menggunakan Model Four-D Materi Statistika
}

\author{
Febriana Eka Yuliafarini* \\ Universitas PGRI Adi Buana Surabaya
}

\begin{abstract}
Abstrak
Matematika sangat berperanan dalam kehidupan sehari-hari. Salah satu alasan rendahnya hasil belajar matematika siswa adalah pembelajaran masih berpusat pada guru. Hal ini berakibat peserta didik tidak aktif dalam proses pembelajaran. Salah satu pembelajaran yang dapat mengaktifkan siswa adalah model pembelajaran kooperatif adalah Numbered Heads Together (NHT). Numbered Heads Together (NHT). Model pembelajaran kooperatif $N H T$ belum pernah diterapkan di

Keywords:

pengembangan

perangkat

pembelajaran,

Numbered Heads

Together (NHT), Model

Four-D, statistika.

SMK Negeri 1 Dlanggu, sehingga sejauh ini perangkat pembelajaran untuk materi statistika dengan menggunakan pembelajaran kooperatif $N H T$ belum tersedia. Oleh karena itu perlu dikembangkan perangkat pembelajaran untuk materi statistika dengan menggunakan pembelajaran kooperatif tipe NHT. Penelitian ini merupakan penelitian pengembangan, yaitu mengembangkan perangkat pembelajaran dengan menggunakan model pengembangan 4-D. Adapun perangkat yang dikembangkan adalah 1) RPP, 2) LAS beserta alternatif kunci jawaban, dan 4) THB beserta alternatif kunci jawaban. Hasil dari penelitian ini adalah 1) Proses pengembangan perangkat pembelajaran kooperatif dengan pendekatan structural Numbered Heads Together (NHT) materi statistika di kelas XI RPL 2 SMK Negeri 1 Dlanggu dilakukan dengan mengacu pada pengembangan model 4-D yang dimodifikasi, 2) Hambatan-hambatan yang dihadapi dalam proses pengembangan perangkat pembelajaran kooperatif dengan pendekatan structural Numbered Heads Together (NHT) materi statistika adalah belum tersedianya Lembar Aktivitas Siswa (LAS) yang dapat mengaktifkan siswa dalam kegiatan pembelajaran, kurangnya guru mengeksplore media pembelajaran yang dapat digunakan siswa memahami materi statistika serta penyajian materi oleh guru biasanya teridir dari a) definisi (pengertian konsep), b) contoh soal dan latihan soal sehingga siswa cenderung pasif dalam pembelajaran, 3) perangkat pembelajaran yang dikembangkan berkualitas baik dengan memenuhi kriteria valid, praktis dan efektif.
\end{abstract}

\section{PENDAHULUAN}

Pendidikan nasional berfungsi mengembangkan kemampuan dan membantuk watak serta peradaban bangsa yang bermartabat dalam rangka mencerdaskan kehidupan bangsa, bertujuan untuk berkembangnya potensi peserta didik agar menjadi manusia yang beriman dan bertakwa kepada Tuhan Yang Maha Esa, berakhlak mulia, sehat, berilmu, cakap, kreatif, mandiri, dan menjadi warga negara yang demokratis serta bertanggung jawab (UU Nomor 20 tahun 2003). Pendidikan yang mampu mendukung pembangunan di masa depan adalah pendidikan yang mampu mengembangkan potensi peserta didik, sehingga yang bersangkutan harus mampu menerapkan apa yang dipelajari di sekolah untuk menghadapi masalah yang dihadapi dalam kehidupan sehari-hari saat ini maupun yang akan datang. Salah satu bidang studi yang mempunyai peranan penting dalam dunia pendidikan dan dalam menghadapi masalah kehidupan seharihari adalah matematika. Walaupun tidak semua permasalahan-permasalahan itu

* Corresponding author.

E-mail Addresses: - febri.smkdlg@gmail.com (Febriana Eka Yuliafarini) 
termasuk permasalahan matematis, namun matematika memiliki peranan penting dalam menjawab permasalahan keseharian (Dyahsih, 2015).

Pendidikan lebih dari sekedar pengajaran, yang dapat dikatakan sebagai suatu proses transfer ilmu, transformasi nilai, dan pembentukan kepribadian dengan segala aspek yang dicakupnya. Dengan demikian pengajaran lebih berorientasi pada pembentukan spesialis atau bidangbidang tertentu, oleh karena itu perhatian dan minatnya lebih bersifat teknis. Pendidikan merupakan suatu proses yang diperlukan untuk mendapatkan keseimbangan dan kesempurnaan dalam perkembangan individu maupun masyarakat. Penekanan pendidikan dibanding dengan pengajaran terletak pada pembentukan kesadaran dan kepribadian individu atau masyarakat di samping transfer ilmu dan keahlian. Dengan proses semacam ini suatu bangsa atau negara dapat mewariskan nilai-nilai keagamaan, kebudayaan, pemikiran dan keahlian kepada generasi berikutnya, sehingga mereka betul-betul siap menyongsong masa depan kehidupan bangsa dan negara yang lebih cerah (Nurkholis, 2013).

Fungsi pendidikan sebenarnya adalah menyediakan fasilitas yang dapat memungkinkan tugas pendidikan dapat berjalan lancar, baik secara struktural, maupun secara institusional. Secara struktural menuntut terwujudnya struktur organisasi yang mengatur jalannya proses kependidikan. Secara institusional mengandung implikasi bahwa proses kependidikan yang terjadi dalam struktur organisasi itu dilembagakan untuk lebih menjamin proses pendidikan itu berjalan secara konsisten dan berkesinambungan mengikuti kebutuhan dan perkembangan manusia yang cenderung ke arah tingkat kemampuan yang optimal (Saat, 2015).

Sekolah Matematika merupakan ilmu universal yang mendasari perkembangan teknologi modern, mempunyai peran penting dalam berbagai disiplin dan memajukan daya pikir manusia. Matematika bukanlah ilmu yang hanya untuk keperluan dirinya sendiri, tetapi ilmu yang bermanfaat untuk sebagian besar ilmu-ilmu lain. (Hudojo, 1988:74).

Berkaitan dengan rendahnya prestasi matematika peserta didik, Marpuang (dalam Usman, 2005:3) menyatakan bahwa hal ini mungkin ada kaitannya dengan proses pembelajaran di kelas yang lebih berorientasi pada target kurikulum, yaitu guru berpandangan bahwa tugas utama mereka menyelesaikan bahan pelajaran yang termuat dalam program pengajaran, bukan membantu peserta didik memahami materi yang mereka pelajari. Hal ini juga terjadi di sekolah tempat penulis bertugas selama ini.

Salah satu pembelajaran matematika yang dapat mengaktifkan siswa dalam pembelajaran adalah pembelajaran kooperatif.

Pembelajaran kooperatif numbered head together (NHT) adalah satu tipe pembelaran kooperatif yang menekankan pada struktur khusus yang dirancang untuk mempengaruhi pola interaksi siswa dan memiliki tujuan untuk meningkatkan penguasaan akademik. "Model pembelajaran kooperatif tipe numbered head together ini pertama kali dikembangkan Spenser Kagen untuk melibatkan bamyak siswa dalam menelaah materi yang tercakup dalam suatu pembelajaran tersebut". Lorina (2012:9). Pembelajaran NHT merupakan tipe pembelajaran yang dirancang untuk mempengaruhi pola interaksi siswa dan memiliki tujuan untuk meningkatkan semangat semangat kerjasama dalam kelompok serta memberikan kesempatan kepada siswa untuk saling membagi ide-ide dan mendiskusikan jawaban yang paling tepat. Lorina (2012:9) (Wahyuddin, 2017).

Salah satu model pembelajaran kooperatif yang dapat digunakan ialah model pembelajaran Numbered Heads Together (NHT). Menurut Lie (2002) Numbered Heads Together (NHT) atau kepala bernomor adalah suatu tipe dari pengajaran kooperatif pendekatan struktural yang memberikan kesempatan kepada siswa untuk saling membagikan ide-ide dan mempertimbangkan jawaban yang paling tepat. Selain itu, Numbered Heads Together juga mendorong siswa untuk meningkatkan semangat kerjasama mereka. Model ini dapat digunakan untuk semua mata pelajaran dan untuk semua tingkatan peserta didik. Satu aspek penting dalam pengajaran kooperatif adalah bahwa disamping pengajaran kooperatif membantu mengembangkan tingkah laku kooperatif dan hubungan yang lebih baik diantara siswa, pengajaran kooperatif secara bersamaan membantu siswa dalam pengajaran akademis mereka (Nursyamsi, 2016).

Salah satu model pembelajaran kooperatif adalah Numbered Heads Together (NHT). Numbered Heads Together (NHT) dikembangkan oleh Spencer Kagan pada tahun 1993 (Arends, 1997:122).

Model pembelajaran kooperatif $N H T$ belum pernah diterapkan di SMK Negeri 1 Dlanggu, sehingga sejauh ini perangkat pembelajaran untuk materi statistika dengan menggunakan pembelajaran kooperatif NHT belum tersedia. Oleh karena itu perlu dikembangkan perangkat pembelajaran untuk materi statistika dengan menggunakan pembelajaran kooperatif tipe $N H T$.

Berdasarkan uraian di atas maka peneliti ingin mengembangkan perangkat pembelajaran kooperatif dengan pendekatan structural Numbered Heads Together (NHT) untuk materi statistika di kelas XI RPL 2 SMK Negeri 1 Dlanggu dengan menggunakan model Four-D. 


\section{Pengertian Pembelajaran Kooperatif}

Pembelajaran kooperatif adalah model pembelajaran dengan penekanan pada aspek sosial dalam pembelajaran menggunakan kelompok-kelompok kecil terdiri dari 4 sampai 6 siswa yang sederajat secara heterogen untuk menghasilkan pemikiran dan tantangan miskonsepsi siswa sebagai unsur kuncinya (Slavin, 2009: 8).

2. Karakteristik Pembelajaran Kooperatif

Model pembelajaran kooperatif dikembangkan untuk mencapai paling tidak tiga tujuan pembelajaran penting, yaitu hasil belajar akademik, penerimaan terhadap keragaman, dan pengembangan keterampilan sosial (Ibrahim dkk, 2005:7) Langkah-langkah model pembelajaran kooperatif sebagai berikut.

Tabel 1. Fase Model Pembelajaran Kooperatif

\begin{tabular}{|c|c|}
\hline Fase & Tingkah laku guru \\
\hline $\begin{array}{l}\text { Fase } 1 \\
\text { Menyampaikan } \\
\text { memotivasi siswa } \\
\end{array}$ & $\begin{array}{l}\text { Guru menyampaikan semua tujuan pelajaran tersebut dan } \\
\text { memotivasi siswa belajar }\end{array}$ \\
\hline $\begin{array}{l}\text { Fase }-2 \\
\text { Menyajikan informasi }\end{array}$ & 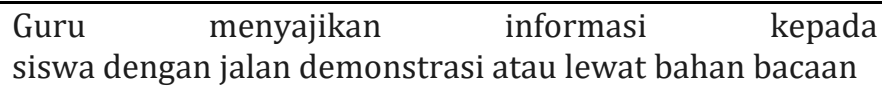 \\
\hline $\begin{array}{l}\text { Fase-3 } \\
\text { Mengorganisasikan siswa ke dalam } \\
\text { kelompok-kelompok belajar }\end{array}$ & $\begin{array}{lccr}\text { Guru } & \text { menjelaskan } & \text { kepada } & \text { siswa } \\
\text { bagaimana } & \text { caranya membentuk } & \text { kelompok } & \text { belajar dan } \\
\text { membantu } & & \text { setiap } \\
\text { kelompok agar melakukan transisi secara evisien } & \\
\end{array}$ \\
\hline $\begin{array}{l}\text { Fase - } 4 \\
\text { Membimbing kelompok, belajar mengajar }\end{array}$ & $\begin{array}{l}\text { Guru } \\
\text { membimbing kelompok-kelompok belajar pada saat } \\
\text { mengerjakan tugas }\end{array}$ \\
\hline $\begin{array}{l}\text { Fase }-5 \\
\text { Evaluasi }\end{array}$ & $\begin{array}{l}\text { Guru mengevaluasi } \text { hasil belajar } \\
\text { tentang materi yang telah dipelajari atau masing-masing } \\
\text { kelompok } \\
\text { mempersentasikan hasil pekerjaannya }\end{array}$ \\
\hline $\begin{array}{l}\text { Fase-6 } \\
\text { Memberi penghargaan }\end{array}$ & $\begin{array}{l}\text { Guru } \quad \text { mencari } \\
\text { menghargai baik hasil belajar individu atau kelompok. }\end{array}$ \\
\hline
\end{tabular}

(Ibrahim dkk, 2005: 7)

A. Pembelajaran Kooperatif dengan Pendekatan Struktural Numbered Heads Together (NHT)

Pendekatan structural adalah salah satu pendekatan dalam pembelajaran kooperatif yang dikembangkan oleh Spencer Kagan (Ibrahim, dkk, 2005;25). Sebagai ganti memberikan pertanyaan kepada seluruh kelas, guru menggunakan struktur empat langkah berikut.

Tabel 2. Struktur Empat Langkah $N H T$

\begin{tabular}{ll}
\hline Langkah 1 & $\begin{array}{l}\text { Numbering (penomoran) } \\
\text { Guru membagi siswa menjadi beberapa kelompok beranggotakan tiga sampai lima orang } \\
\text { dan memberi nomor sehingga setiap siswa dalam kelompok memiliki nomor yang } \\
\text { berbeda dari 1 sampai 5 }\end{array}$ \\
\hline Langkah 2 & $\begin{array}{l}\text { Questioning (Pengajuan Pertanyaan) } \\
\text { Guru mengajukan sebuah pertanyaan kepada siswa. Pertanyaan ini bisa bervariasi. } \\
\text { Pertanyaan bisa sangat spesifik dan dalam bentuk pertanyaan, bisa pula direktif. }\end{array}$ \\
\hline Langkah 3 & $\begin{array}{l}\text { Heads Together (Berpikir Bersama) } \\
\text { Siswa menyatukan pemikiran mereka untuk menemukan jawaban pertanyaan dan } \\
\text { memastikan bahwa semua orang dalam kelompok mengetahui jawabannya. }\end{array}$ \\
\hline Langkah 4 & $\begin{array}{l}\text { Answering (Menjawab) } \\
\text { Guru memanggil sebuah nomor dan siswa dari tiap-tiap kelompok yang memiliki nomor } \\
\text { tersebut mengangkat tangannya dan memberikan jawabannya kepada seluruh kelas. }\end{array}$ \\
\hline
\end{tabular}




\section{B. Perangkat Pembelajaran}

Agar proses pembelajaran dapat berjalan dengan baik perlu dibuat perangkat pembelajaran. Tujuan utama dari penelitian ini adalah untuk menghasilkan perangkat pembelajaran matematika dengan pendekatan structural NHT yang berkualitas baik. Berikut ini dijelaskan tentang komponen perangkat pembelajaran dan uraian tentang kriteria perangkat pembelajaran yang berkualitas baik.

Menurut Ibrahim (dalam Trianto, 2007:68) perangkat pembelajaran yang diperlukan guru dalam mengelola proses belajar mengajar meliputi: Buku Siswa, Silabus, Rencana Pelaksanaan Pembelajaran (RPP), Lembar Kegiatan siswa (LKS), Instrumen Evaluasi (THB), serta Media pembelajaran.Mengacu pada jenis perangkat pembelajaran yang dikemukakan tersebut, maka perangkat pembelajaran yang dikembangkan dalam mengelola pembelajaran pada penelitian ini adalah: Rencana Pelaksanaan Pembelajaran (RPP), Lembar Kerja Siswa (LKS) dengan kunci, dan Tes Hasil Belajar (THB) dengan kunci yang disusun berdasarkan kurikulum yang berlaku di sekolah.

C. Kriteria Perangkat Pembelajaran Yang Berkualitas Baik

Menurut Nieven (1999: 127) perangkat pembelajaran dikatakan berkualitas baik apabila memenuhi kriteria valid, praktis dan efektif.

D. Model Pengembangan Perangkat Model Four - D

Penelitian ini menggunakan model pengembangan perangkat pembelajaran Thiagarajan dkk (Thiagarajan, Semmel dan Semmel, 1974:5) yang juga dikenal dengan Four-D Model atau model 4-D yang telah dimodifikasi. Langkah-langkah pengembangan Model Four-D dapat dilihat seperti gambar berikut.
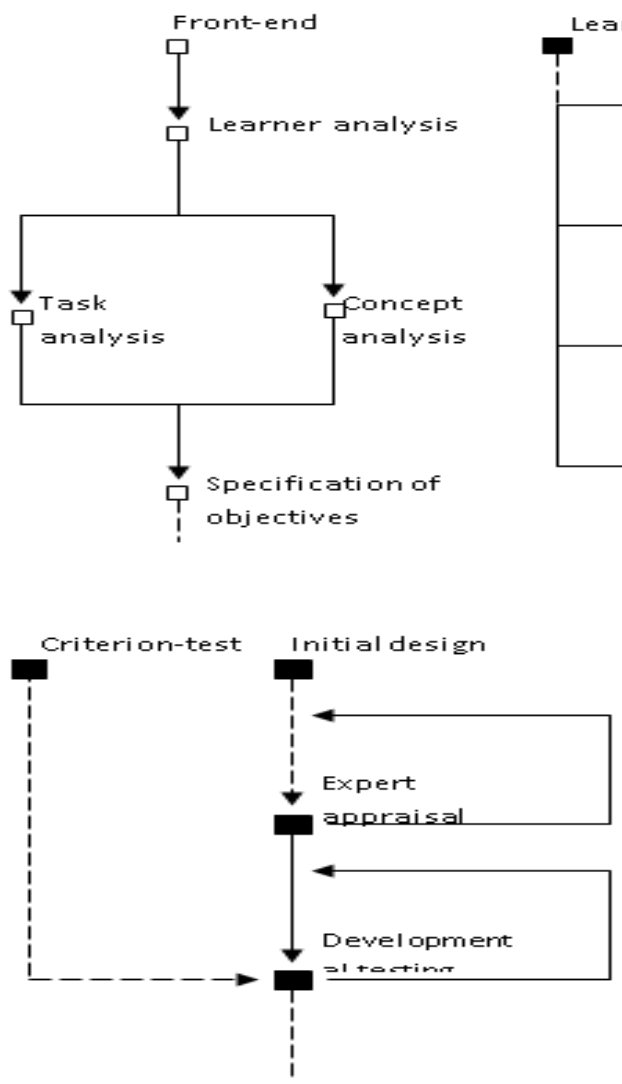
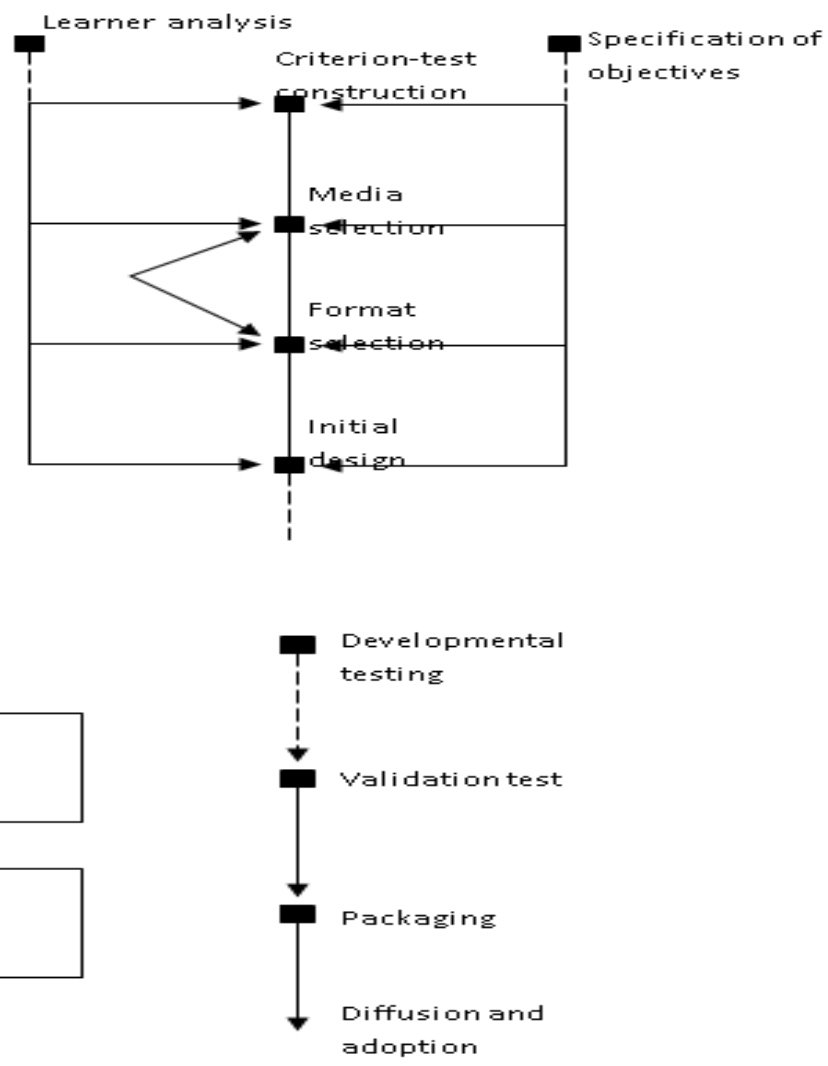

Gambar 1. Tahap Pengembangan Perangkat Pembelajaran Model 4-D

\section{E. Materi Statistika}

Berdasarkan kurikulum 2013 revisi materi statistika diberikan di kelas XI. Adapun kompetensi dasar yang diberikan adalah sebagai berikut. 


\section{METODE PENELITIAN}

Berdasarkan masalah penelitian yang telah dipaparkan sebelumnya, maka jenis penelitian yang akan dilakukan yaitu penelitian pengembangan perangkat pembelajaran. Perangkat pembelajaran yang akan dikembangkan adalah rencana pelaksanaan pembelajaran (RPP), Lembar Aktivitas Siswa (LAS), dan Tes Hasil Belajar (THB). Penelitian mengikuti Model 4-D yang terdiri empat tahap, yaitu define (pendefinisian), design (perancangan), develop (pengembangan) dan disseminate (pendiseminasian). Berikut akan dijelaskan mengenai prosedur pengembangan perangkat dalam penelitian ini.

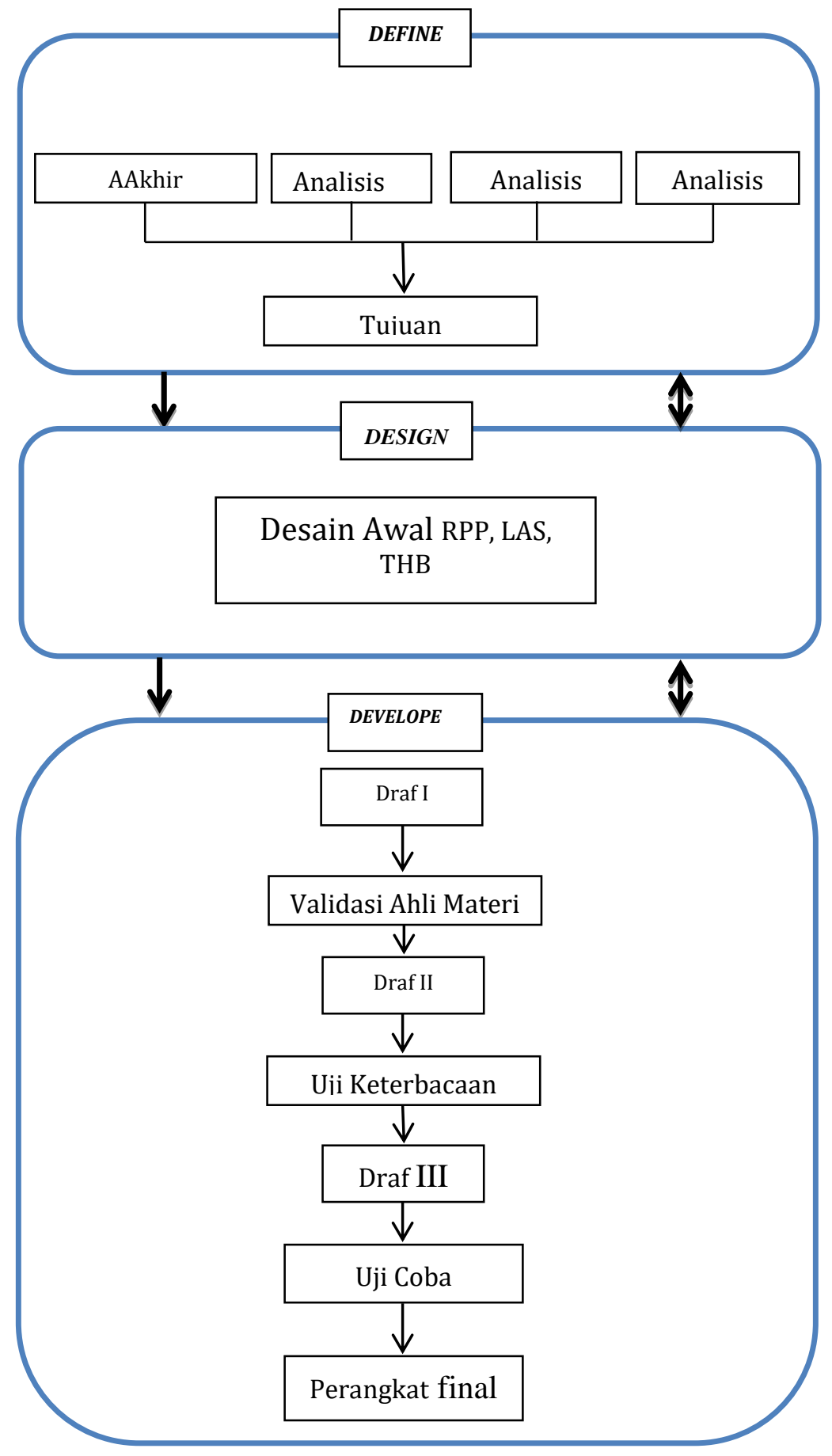

Gambar 2. prosedur pengembangan perangkat 
1) Define (Pendefinisian)

Adapun kegiatan dalam tahap ini adalah sebagai berikut: Analisis Awal-Akhir, Analisis Siswa,

Analisis Tugas, Analisis Materi.

a. Mengevaluasi kajian statistika dalam masalah kontekstual

b. Menyelesaikan masalah kontekstual yang berkaitan dengan kajian statistika

2) Design (Perancangan)

Tahap ini bertujuan untuk menghasilkan rancangan perangkat pembelajaran yang berorientasi pada pembelajaran kooperatif NHT. Kegiatan yang dilakukan pada tahap ini adalah merancang perangkat pembelajaran yang meliputi Rencana Pelaksanaan Pembelajaran (RPP), Lembar Aktivitas Siswa (LAS) dan Tes Hasil Belajar (THB). Hasil perancangan awal ini disebut Draf I.

3) Develop (Pengembangan)

Tujuan tahap ini adalah untuk menghasilkan draf final yaitu draf perangkat pembelajaran yang direvisi berdasarkan masukan-masukan para ahli dan data yang diperoleh dari uji coba lapangan. Kegiatan pada tahap ini meliputi validasi ahli, uji keterbacaan, dan uji coba lapangan.

Adapun langkah-langkah uji lapangan adalah sebagai berikut:

a. Subjek Uji Coba

Subjek uji coba lapangan dilaksanakan di kelas XI RPL 2 SMK Negeri 1 Dlanggu tahun pelajaran 2018/2019. Jumlah siswa uji coba sebanyak 35 siswa.

b. Dalam pelaksanaan uji coba lapangan, pembelajaran dilaksanakan oleh guru mitra. Pada setiap pertemuan dilakukan pengamatan terhadap kemampuan guru mengelola pembelajaran dan aktivitas siswa selama pembelajaran.

1. Instrumen Pengumpulan Data

Instrumen pengumpulan data yang digunakan dalam penelitian ini adalah lembar validasi perangkat pembelajaran, lembar observasi kemampuan guru mengelola pembelajaran, lembar observasi aktivitas siswa selama pembelajaran, angket respons siswa dan tes hasil belajar.

2. Teknik Analisis Data

a. Data Validasi Perangkat

b. Data Observasi Kemampuan Guru Mengelola Pembelajaran

c. Data Observasi Aktivitas Siswa Selama Pembelajaran

d. Data Respon Siswa

e. Data Tes Hasil Belajar

\section{ANALISIS DAN PEMBAHASAN}

Salah satu tujuan Penelitian Salah satu tujuan penelitian ini adalah untuk mengetahui proses pengembangan perangkat pembelajaran kooperatif dengan pendekatan structural Numbered Heads Together (NHT) yang berkualitas baik untuk materi statistika di kelas XI RPL 2 SMK Negeri 1 Dlanggu. Dalam proses pengembangan perangkat pembelajaran tersebut, model pengembangan yang digunakan adalah model 4-D yang telah dimodifikasi pada tahap-tahap pengembangannya. Proses dan hasil pengembangan perangkat dapat peneliti deskripsikan sebagai berikut.

1. Tahap Pendefinisian (Define): Analisis Awal-Akhir, Analisis Siswa, Analisis Tugas, Analisis Materi, Spesifikasi Tujuan Pembelajaran

2. Tahap Perancangan (Design)

Pada tahap ini dilakukan perancangan awal Rencana Pelaksanaan Pembelajaran (RPP), Lembar Aktivitas Siswa (LAS), Tes hasil Belajar (THB).

3. Tahap Pengembangan (Develop)

Pada tahap ini kegiatan yang dilakukan terhadap perangkat pembelajaran yang dikembangkan adalah sebagai berikut.

a. Validasi Ahli

Draf I yang dihasilkan diuji oleh validator ahli materi. Validator yang melakukan validasi terhadap perangkat pembelajaran yang dikembangkan (Draf I) terdiri dari satu orang yaitu: Dr. H. Rufi'I, S.Si, ST, M.Pd.

Lembaga: Pascasarjana Universitas PGRI AdiBuana Surabaya

Jabatan : Dosen Matematika Universitas PGRI Adi Buana Surabaya

Draf I diserahkan kepada validator ahli pada tanggal 12 November 2018.

1) Hasil Validasi Lembar Aktivitas Siswa

Hasil penilaian oleh validator ahli terhadap Lembar Aktivitas Siswa (LAS). 


\section{Hasil Penilaian Validasi Ahli Terhadap THB}

Uji Keterbacaan

Dari hasil validasi ahli dan dilakukan revisi terhadap perangkat pembelajaran maka dihasilkan draf II. Draf II yang dihasilkan kemudian di lakukan uji keterbacaan. Uji keterbacaan dilakukan dengan tujuan untuk mengetahui apakah perangkat pembelajaran yang dikembangkan (Draf II) dapat terbaca dengan jelas dan dapat dipahami oleh siswa.

Uji keterbacaan dilakukan oleh 6 orang siswa kelas XI RPL 1 yang mempunyai kemampuan akademik yang beragam ( tinggi, sedang dan rendah). Keenam siswa ini bukan berasal dari kelas uji coba.

Uji keterbacaan oleh siswa dilakukan terhadap LAS dan soal latihan individu. Para siswa yang menjadi responden uji keterbacaan, pada umumnya menyatakan bahwa LAS dan soal individu yang digunakan sudah baik dan dapat dipahami dengan jelas, sehingga perangkat pembelajaran tersebut tidak perlu direvisi.

Guru yang menjadi subjek dalam uji keterbacaan adalah 1 orang guru mitra. Sebagai guru mitra adalah Guru Matematika SMK Negeri 1 Dlanggu yaitu Bapak Frans Umila, S.Pd. Uji keterbacaan oleh guru mitra dilakukan terhadap perangkat pembelajaran (draf II) yaitu RPP, LAS, Soal Individu dan THB. Hasil uji keterbacaan oleh guru mitra adalah perangkat pembelajaran dapat dibaca dan dipahami dengan jelas, dengan revisi sedikit di RPP. Perangkat pembelajaran yang dikembangkan yang sudah divalidasi oleh validasi ahli dan uji keterbacaan dalam hal ini disebut dengan draf III, kemudian diujicobakan di kelas XI RPL 2 SMKN 1 Dlanggu Mojokerto dengan jumlah siswa sebanyak 35 siswa. Uji coba dilakukan sebanyak 2 kali pertemuan sesuai dengan RPP yang telah dibuat. Dari hasil uji coba terhadap perangkat pembelajaran diperoleh data sebagai berikut: (1) data kemampuan guru mengelola pembelajaran, (2) data aktivitas siswa selama pembelajaran, (3), Respon siswa terhadap pembelajaran dan (4) data tes hasil belajar (pre test dan post test). Data-data tersebut kemudian dianalisis untuk mengetahui kualitas dari perangkat pembelajaran yang dikembangkan.

Dalam pelaksanaan uji coba, guru yang bertindak sebagai pengajar adalah Frans Umila, S.Pd. Selain itu dalam uji coba ini juga melibatkan dua orang pengamat, yaitu 1) Sasmiati, M.Pd., sebagai pengamat yang bertugas untuk mengamati kemampuan guru dalam mengelola pembelajaran, dan 2) Agustin Wahyu M., S.Pd, sebagai pengamat yang bertugas mengamati aktivitas siswa selama pembelajaran.

\section{Analisis Data Hasil Uji Coba}

a. Analisis Data Kemampuan Guru Mengelola Pembelajaran

Berdasarkan hasil observasi kemampuan guru mengelola pembelajaran selama dua kali pertemuan terlihat bahwa nilai setiap aspek pengamatan adalah 4 dan 5 . Hal ini berarti kemampuan guru mengelola pembelajaran memenuhi kategori baik dan sangat baik. Nilai rata-rata secara keseluruhan adalah sebesar 4.65. Berdasarkan kriteria kemampuan guru mengelola pembelajaran pada Bab III, maka kemampuan guru mengelola pembelajaran dapat dikatakan efektif.

b. Analisis Data Aktivitas Siswa Selama Pembelajaran

Hasil observasi aktivitas siswa dengan menggunakan pembelajaran kooperatif NHT selama 2 kali pertemuan dinyatakan dalam persentase.

c. Analisis Data Respon Siswa Terhadap Pembelajaran

Data respon siswa terhadap pembelajaran diperoleh dari angket yang diberikan kepada siswa setelah mengikuti pembelajaran menggunakan NHT. Data respon siswa dianalisis dengan menggunakan persentase.

d. Analisis Data Tes Hasil Belajar (THB)

Data tes hasil belajar ini dianalisi secara deskriptif. Data tes hasil belajar diperoleh dari pretest dan posttest.

Berdasarkan analisis data menunjukkan bahwa perangkat pembelajaran kooperatif dengan pendekatan structural Numbered Heads Together (NHT) untuk materi statistika di kelas XI RPL 2

1) Valid SMK Negeri 1 Dlanggu berkualitas baik, karena memenuhi kriteria valid, praktis dan efektif.

Perangkat pembelajaran yang dikembangkan telah dinyatakan valid oleh validator.

2) Praktis

a. Perangkat pembelajaran yang dikembangkan dapat digunakan dengan kategori penilaian baik.

b. Perangkat pembelajaran yang dikembangkan terbaca baik oleh siswa.

c. Kemampuan guru mengelola pembelajaran memenuhi kategori baik dan sangat baik.

d. Hasil observasi aktivitas siswa dalam kegiatan pembelajaran sesuai dengan alokasi waktu yang ada dalam RPP.

3) Efektif

a. Respon siswa terhadap komponen pembelajaran positif. 
Hasil belajar siswa mencapai ketuntasan belajar secara klasikal mencapai $\geq 80 \%$.

b. Revisi Produk

Berdasarkan saran dan masukan dari validator ahli maka perlu dilakukan beberapa revisi kecil untuk perbaikan perangkat pembelajaran yang dikembangkan. Adapun revisi dari validator ahli adalah sebagai berikut: 1. Revisi Rencana Pelaksanaan Pembelajaran (RPP), 2. Revisi Lembar Aktivitas Siswa (LAS), 3. Revisi Tes Hasil Belajar (THB)

\section{KESIMPULAN}

Berdasarkan hasil model pengembangan perangkat yang diuraikan pada Bab IV maka dapat disimpulkan sebagai berikut.

1. Proses pengembangan perangkat pembelajaran kooperatif dengan pendekatan structural Numbered Heads Together (NHT) materi statistika di kelas XI RPL 2 SMK Negeri 1 Dlanggu dilakukan dengan mengacu pada pengembangan model 4-D yang dimodifikasi. Adapun tahap-tahap yang dilakukan adalah sebagai berikut.

a. Tahap pendefinisian (Define)

Tahap ini dimulai dengan melakukan analisis awal akhir, analisis siswa, analisis materi, analisis tugas. Selanjutnya berdasarkan analisis tersebut digunakan untuk menentukan tujuan pembelajaran.

b. Tahap Perancangan (Design)

Pada tahap ini disusun rancangan awal Rencana Pelaksanaan Pembelajaran (RPP), Lembar Aktivitas Siswa (LAS), soal tes individu dan Tes Hasil Belajar (THB). Rancangan ini disebut sebagai draf I.

c. Tahap Pengembangan (Develop).

Hasil rancangan awal yang disebut draf I kemudian divalidasi oleh validator ahli. Hasil validasi oleh validator ahli disebut dengan draf II. Hasil draf II kemudain dilakukan uji keterbacaan kepada siswa dan guru yang mengajar. Hasil masukan dari uji keterbacaan kemudian direvisi dan dinamakan dengan draf III. Hasil draf III kemudian diujicobakan di kelas XI RPL 2 SMKN 1 Dlanggu.

2. Hambatan-hambatan yang dihadapi dalam proses pengembangan perangkat pembelajaran kooperatif dengan pendekatan structural Numbered Heads Together (NHT) untuk materi statistika adalah belum tersedianya Lembar Aktivitas Siswa (LAS) yang dapat mengaktifkan siswa dalam kegiatan pembelajaran, kurangnya guru mengeksplore media pembelajaran yang dapat digunakan siswa memahami materi statistika serta penyajian materi oleh guru biasanya terdiri dari a) definisi (pengertian konsep), b) contoh soal dan latihan soal sehingga siswa cenderung pasif dalam pembelajaran.

3. Berdasarkan analisis data menunjukkan bahwa perangkat pembelajaran kooperatif dengan pendekatan structural Numbered Heads Together (NHT) untuk materi statistika di kelas XI RPL 2 SMK Negeri 1 Dlanggu berkualitas baik, karena sudah memenuhi kriteria:

a. valid, yaitu perangkat yang dikembangkan telah dinyatakan valid oleh validator dengan hasil ratarata penilaian RPP adalah 3.5, hasil rata-rata penilaian LAS adalah 3.62 dan hasil rata-rata penilaian THB adalah 3.67 .

b. Praktis, yaitu 1) validator menyatakan perangkat yang dikembangkan dapat digunakan, 2) perangkat yang dikembangkan terbaca baik oleh siswa, 3) kemampuan guru mengelola pembelajaran menggunakan pembelajaran koperatif dengan pendekatan structural Numbered Heads Together (NHT) memenuhi kategori baik dan sangat baik hal itu ditunjukkan dari hasil rata-rata secara keseluruhan 4.65 yang berarti pembelajaran dikatakan efektif, (d) aktivitas siswa dalam kegiatan pembelajaran efektif karena persentase setiap aspek pengamatan aktivitas siswa pada setiap RPP sesuai dengan waktu ideal yang ditentukan dengan toleransi $10 \%$.

c. Efektif yang ditandai dengan respon siswa terhadap pembelajaran positif dengan nilai $84.76 \%$ dan ketuntasan belajar klasikal mencapai nilai $\geq 80 \%$ yaitu sebesar $82.86 \%$.

Berdasarkan kesimpulan di atas, maka saran yang dapat diberikan oleh peneliti adalah sebagai berikut; a)Perangkat pembelajaran kooperatif dengan pendekatan structural NHT sudah berkualitas biak, sehingga dapat digunakan sebagai alternatif untuk mengajarkan materi statistika, b) Hambatan-hambatan yang dihadapi dalam pengembangan perangkat pembelajaran kooperatif dengan pendekatan structural NHT salah satunya adalah kurangnya guru mengeksplore penggunaan media, c) Respon siswa terhadap pembelajaran kooperatif dengan pendekatan structural NHT adalah positif, oleh karena itu disarankan kepada guru matematika untuk mengembangkat perangkat pembelajaran kooperatif dengan pendekatan structural NHT untuk materi lain, d) Perangkat pembelajaran yang dihasilkan baru dikembangkan sampai pada tahap pengembangan (develop), sehingga perlu diujicobakan lebih lanjut. Oleh karena itu 
disaranakan pada peneliti yang lain untuk menggunakan perangkat pembelajaran ini untuk melihat keefektifan perangkat pembelajaran menggunakan, dan e) Pembelajaran kooperatif dengan pendekatan structural NHT untuk materi statistika.

\section{DAFTAR PUSTAKA}

Abdurrahman, 2002. Pengembangan Perangkat Pembelajaran Penemuan Terbimbing Pada Topik Bangunbangun Segiempat di Kelas 2 SLTP Negeri 16 Pekanbaru. Makalah Komprehensif. PPs Unesa.

Aiken, L. 1997. Psychology Testing and Assessment (9 ${ }^{\text {th }}$ edition. USA: Allyn and Bacon.

Arends, R.I. 1997. Classroom Instruction and Management. New York: McGraw-Hill.

Arends, R.I. 2001. Learning to Teach, Fifth Edition. New York: McGraw-Hill.

Depdiknas. 2006. Peraturan pemerintah nomor 19 tahun 2006 tentang Standar Nasional pendidikan. Jakarta: Depdiknas

Dyahsih. 2015. Keefektifan Experiential Learning Pembelajaran Matematika Mts Materi Bangun Ruang Sisi Datar. Jurnal Riset Pendidikan Matematika Volume 2 - Nomor 2, November 2015

Effendi, M.J. 2004. Pengembangan Perangkat Pembelajaran Kooperatif Pendekatan Struktural Numbered Heads Together(NHT) untuk Pokok Bahasan Persamaan Garis Lurus di Kelas 2 SLTP. Tesis Magister Pendidikan, Universitas Negeri Surabaya.

Eggen, P.D., dan Kauchak, D.P. 2001. Strategies for Teachers, Teaching Content and Thinking Skills. Fourth Edition. Boston: Allyn and Bacon.

Endang, Mulyatiningsih. 2013. Metode Penelitian Terapan Bidang Pendidikan. Alfabeta. Bandung.

Fadiana. 2008. Pembelajaran Kooperatif dengan Pendekatan Struktural Numbered Heads Together (NHT) pada Pokok Bahasan Persegipanjang dan Persegi Kelas VII SMP Muhammadiyah 5 Surabaya. Surabaya: Tesis PPs Unesa.

Hamdani. 2011. Strategi Belajar Mengajar. Pustaka Setia. Bandung.

Huda, Miftahul. 2013. Model-Model Pengajaran dan Pembelajaran. Pustaka Belajar, Yogyakarta.

Ibrahim, M., Rachmadiarti, F., Nur, M. Ismono. 2005. Pembelajaran Kooperatif. Surabaya : Unesa University Press.

Kemp, J.E, Morrison, G.R., Ross, S.M. 1994. Designing Effective Instruction. New York : Macmillan College Publishing Company.

Komalasari, Kokom. 2014. Pembelajaran Kontekstual (Konsep dan Aplikasi). Refika Aditama. Bandung.

Mustaji, dkk. 2017. Kajian Dan Analisis Teknologi Pendidikan. Surabaya: CV Bintang.

Nursyamsi SY. 2016. Pengaruh Strategi Pembelajaran Numbered Heads Together (Nht) Terhadap Hasil Belajar Siswa Sma Negeri 1 Muara Badak. Jurnal Pendidikan: Teori, Penelitian, dan Pengembangan Volume: 1 Nomor: 10 Bulan Oktober Tahun 2016 Halaman: 1993-1998

Nurkholis. 2013. Pendidikan Dalam Upaya Memajukan Teknologi . Jurnal Kependidikan, Vol. 1 No. 1 Nopember 2013

Nieven, dkk. 1999. Design Approaches and Tools in Education and Training. Kluwer Academy Publiser. Netherlands 
Saat ,Sulaiman. 2015. Faktor-Faktor Determinan Dalam Pendidikan Studi Tentang Makna Dan Kedudukannya Dalam Pendidikan . Jurnal Al-Ta'dib Vol. 8 No. 2, Juli-Desember

Wahyuddin. 2017. Penerapan Model Pembelajaran Numbered Head Together (NHT) pada Siswa Kelas V SD Negeri 75 Ujungpero Kecamatan Sabbangparu Kabupaten Wajo . Journal of Mathematics Education (p-ISSN: 2477-4758|e-ISSN: 2540-9670) Vol. 3, No. 1, 2017 